\title{
Cytomegalovirus and HIV Persistence: Pouring Gas on the Fire
}

\author{
Aaron Christensen-Quick, Christophe Vanpouille, Andrea Lisco,, and Sara Gianella ${ }^{1}$
}

\begin{abstract}
The inherent stability of a small population of $\mathrm{T}$ cells that are latently infected with HIV despite antiretroviral therapy (ART) remains a stubborn obstacle to an HIV cure. By exploiting the memory compartment of our immune system, HIV maintains persistence in a small subset of quiescent cells with varying phenotypes, thus evading immune surveillance and clinical detection. Understanding the molecular and immunological mechanisms that maintain the latent reservoir will be critical to the success of HIV eradication strategies. Human cytomegalovirus (CMV), another chronic viral infection, frequently co-occurs with HIV and occupies an oversized proportion of memory $\mathrm{T}$ cell responses. CMV and HIV have both evolved complex strategies to manipulate our immune system for their own advantage. Given the increasingly clear links between CMV replication, chronic immune activation, and increased HIV reservoirs, we present a closer examination of the interplay between these two chronic coinfections. Here we review the effects of CMV on the immune system and show how they may affect persistence of the latent HIV reservoir during ART. The studies described herein suggest that hijacking of cytokine and chemokine signaling, manipulation of cell development pathways, and transactivation of HIV expression by CMV might be pouring gas on the fire of HIV persistence. Future interventional studies are required to formally determine the extent to which CMV is causally associated with inflammation and HIV reservoir expansion.
\end{abstract}

Keywords: CMV, HIV, reservoir, persistence, inflammation

\section{Introduction}

NFLAMMATION AND HIV flourish in the presence of each other, and emerging studies suggest that chronic coinfections such as cytomegalovirus (CMV) may contribute to a vicious cycle of immune activation and reservoir seeding. ${ }^{1-3}$ During acute infection, HIV undermines the integrity of the gut mucosal barrier and lymphoid tissue, promoting microbial translocation and the recruitment of target cells to sites of inflammation. ${ }^{4}$ This set of circumstances enables HIV to establish a larger reservoir of latently infected cells, which can hide dormant for decades in the face of virally suppressive antiretroviral therapy (ART). ${ }^{5}$

Three main mechanisms contribute to HIV persistence during suppressive ART: first, the inherent stability and longevity of a small population of resting $\mathrm{T}$ cells that are latently infected with HIV despite long-term suppressive ART. ${ }^{5}$ Second, latently infected cells can proliferate in response to antigenic stimulation or cytokines. ${ }^{6}$ Third, HIV can be expressed at low levels despite ART, especially in certain immunological sanctuaries, promoting immune activation and further enhancing the recruitment of target cells. ${ }^{3}$

The presence of CMV coinfection might add a new dimension to each of these putative mechanisms of HIV persistence. CMV has a high worldwide prevalence with estimates ranging from $40 \%$ to $100 \%$ seropositivity, and establishes a life-long infection characterized by persistent antigen exposure and interaction with the host immune system. CMV prevalence is further concentrated among older people and people living with HIV (seroprevalence of $80 \%-$ $100 \%) .^{7-9}$ In general, CMV is only pathogenic in individuals with deeply compromised immune systems, but people living with HIV often have asymptomatic, ongoing CMV replication in various mucosal sites and effector tissues. ${ }^{10}$ For example, we recently showed that the vast majority of HIVinfected men who have sex with men (MSM) had evidence of persistent CMV replication in their genital secretions at one or multiple time points throughout 1 year of follow-up. ${ }^{11}$

\footnotetext{
${ }^{1}$ University of California San Diego, Center for AIDS Research, La Jolla, California.

${ }^{2}$ Eunice Kennedy Shriver National Institute of Child Health and Human Development, National Institutes of Health, Bethesda, Maryland.

${ }^{3}$ National Institute of Allergy and Infectious Diseases, National Institutes of Health, Bethesda, Maryland.
} 
This subclinical CMV replication has been associated with $\mathrm{T}$ cell dysfunction and with impaired immune recovery after HIV infection. ${ }^{12,13,14}$ As we discuss in this review, persistent CMV replication can also promote longevity and proliferation of HIV-infected cells, the recruitment of new HIV target cells, and directly enhance HIV transcription. Taken together, we hypothesize that coinfection with CMV could be an important factor contributing to the establishment and maintenance of the HIV reservoir during ART.

\section{Coinfection and HIV Persistence}

Recent studies suggest that coinfections such as CMV can exacerbate HIV-related chronic immune activation during ART, and might augment the size of the latent HIV reservoir. $^{1,2,15}$ For example, a longitudinal study following 107 men starting ART during the earliest phase of their HIV infections (median 3 months since estimated date of infection) over a median follow-up period of 19 months observed an association between presence of CMV and Epstein-Barr virus (EBV) replication in peripheral blood mononuclear cells and slower decay rate of the HIV DNA reservoirs during ART. ${ }^{1}$ Other cross-sectional studies demonstrated that subclinical CMV replication is associated with higher levels of HIV DNA in both ART-naive and ART-suppressed individuals. $^{2,16}$ Interestingly, in a small cohort of people living with HIV who underwent myeloablative chemotherapy, HIV DNA was enriched in CMV- and EBV-specific $\mathrm{CD}^{+}{ }^{+} \mathrm{T}$ cells after immune reconstitution. ${ }^{15}$ Although we cannot infer causality due to the observational design of these studies, these findings support a model in which CMV replication, increased HIV reservoirs, and inflammation are inextricably linked.

A variety of possible concurrent mechanisms may account for the relationship between CMV and HIV persistence. Specifically, CMV may promote HIV persistence through (1) altered chemokine receptor-mediated cell trafficking to sites of inflammation, (2) induction of inhibitory immune pathways (e.g., cellular exhaustion, PD-1, and IL-10 expression), (3) proliferation and clonal expansion of HIV-target cells, (4) inhibition of apoptosis, and/or (5) direct transactivation of latent HIV (Fig. 1). Here, we review what is known about these mechanisms in the context of HIV and CMV coinfection.

\section{Inflammation and altered chemokine trafficking}

In a complex host-virus relationship, CMV elicits and maintains a high frequency of virus-specific $\mathrm{T}$ cells that engage in a life-long effort to restrain CMV replication and prevent disease. ${ }^{8,17}$ Since CMV replication is enhanced by inflammatory stimuli, the virus developed ingenious strategies to induce and augment inflammation. ${ }^{18}$ For example, CMV directly upregulates the expression of several cytokines and inflammatory mediators in host cells, including IL- $1 \beta$, IL-6, and type I interferon, triggering inflammatory responses. ${ }^{19-22} \mathrm{CMV}$ and other herpesviruses can also upregulate IL- $15,{ }^{23}$ which is a common $\gamma$-chain cytokine like IL-2 and IL-7. This group of cytokines can promote the expansion of $\mathrm{CD}^{+}$and $\mathrm{CD}^{+} \mathrm{T}$ cells independently of antigen specificity, making them particularly relevant to the HIV reservoir. ${ }^{23-25}$

CMV encodes its own cytokines and chemokine homologues as well as cytokine receptor homologues that can further modulate levels of human cytokines, chemokines, and growth factors. ${ }^{19,26,27}$ For example, CMV alters the expres- sion of the chemokines RANTES, MCP-1a, and IL- $8,{ }^{28}$ and at least six CMV genes (UL33, UL78, UL146, UL147, US27, and US28) encode chemokine-receptor-like protein. Furthermore, CMV-exposed central memory $\mathrm{T}$ cells from cord blood mononuclear cells demonstrated increased expression of CCR5 protein, ${ }^{29}$ which is the main coreceptor for HIV cellular entry. ${ }^{30}$ Taken together, the CMV-induced proinflammatory milieu and disrupted chemokine trafficking could promote the influx of HIV target cells at sites of HIV persistence.

Consistent with our hypothesis that CMV increases HIV persistence by recruiting HIV target cells to sites of inflammation, a recent study of ART-treated people living with HIV demonstrated that CMV replication in the gut was associated with disrupted mucosal barrier integrity, microbial translocation, and inflammation. ${ }^{3} \mathrm{CMV}$-induced inflammation in the gut — a major site of HIV replication-likely attracts HIV target cells or increases the susceptibility of the local immune milieu to HIV infection. ${ }^{3,31}$ The specific effects of CMV replication and $\mathrm{CMV}$-induced inflammation on the trafficking of HIV target cells remain poorly defined in humans, but merit deeper investigation. The hijacking of cytokine and chemokine signaling by CMV leads to an inflammatory environment that is ripe with HIV target cells.

\section{Induction of inhibitory immune pathways}

Not only does CMV induce inflammation but it can also hinder immunity directed toward CMV-infected cells, ${ }^{32,33}$ which may have important implications for HIV persistence. Like HIV, CMV can inhibit human leukocyte antigen (HLA) expression on cellular surfaces, thereby impairing antigen presentation. $^{34}$ However, compared with HIV, the larger genome of CMV allows for an expanded arsenal of immune modulatory factors. ${ }^{28,32,34}$ For example, CMV can produce decoy viral homologues of HLA class I molecules that allow it to avoid immunosurveillance by natural killer (NK) cells. ${ }^{32}$ Such immune diversions-developed by CMV over millions of years of coexistence with the human species-could favor immune evasion not only for CMV itself but also for other coinfecting viruses, such as HIV.

CMV has also evolved strategies to hijack cell-signaling pathways, such as PD-1 and IL-10, and the disrupted signaling may coincidentally promote HIV persistence. ${ }^{14,26,27,33,35,36}$ For example, in a recent study of 45 MSM who were virally suppressed on ART, seminal CMV shedding was associated with increased PD-1 expression on $\mathrm{CD}^{+}{ }^{+} \mathrm{T}$ cells. ${ }^{14}$ This may be important because HIV-specific T cells are enriched in PD-1 expression, and PD-1 expression on $\mathrm{CD}^{+} \mathrm{T}$ cells is positively correlated with HIV viremia. ${ }^{37,38}$ Induction of PD-1 signaling on $\mathrm{CD}^{+} \mathrm{T}$ cells has been postulated as a mechanism to enable recently infected $\mathrm{CD}^{+}{ }^{+} \mathrm{T}$ cells to shift toward a state of persistence, rather than one of activation-induced cell death. ${ }^{39,40}$ PD-1 expressing $\mathrm{CD}^{+} \mathrm{T}$ cells are highly enriched with integrated HIV DNA, ${ }^{39}$ and expression of PD- 1 by $\mathrm{CD}^{+} \mathrm{T}$ cells causes impaired HIV-specific immunity. ${ }^{41,42}$

IL-10 is a cytokine that promotes tolerance and potently stifles the proinflammatory activities of many immune cell types by (1) promoting the development of regulatory $\mathrm{T}$ cells, (2) diminishing the proliferative capacity of lymphocytes, (3) inhibiting the ability of monocytes to activate T cells in response to antigen, (4) skewing the cytokine expression of monocytes, and (5) blunting the effector functions of lymphocytes 
FIG. 1. Putative mechanisms by which CMV might promote HIV persistence. Cells harboring latent HIV could become more numerous through CMV-associated inflammation, inhibitory signaling, proliferation, or inhibition of apoptosis. CMV can also directly transactivate latent HIV, which could lead to more target cells becoming infected. Blue circles with nucleus represent CD4 $\mathrm{T}$ cells with and without integrated HIV DNA; purple dots represent inhibitory cytokines; orange circles represent HIV. Gray circles represent CMV. Squared cells represent epithelial cells with signs of inflammation. CMV, cytomegalovirus.

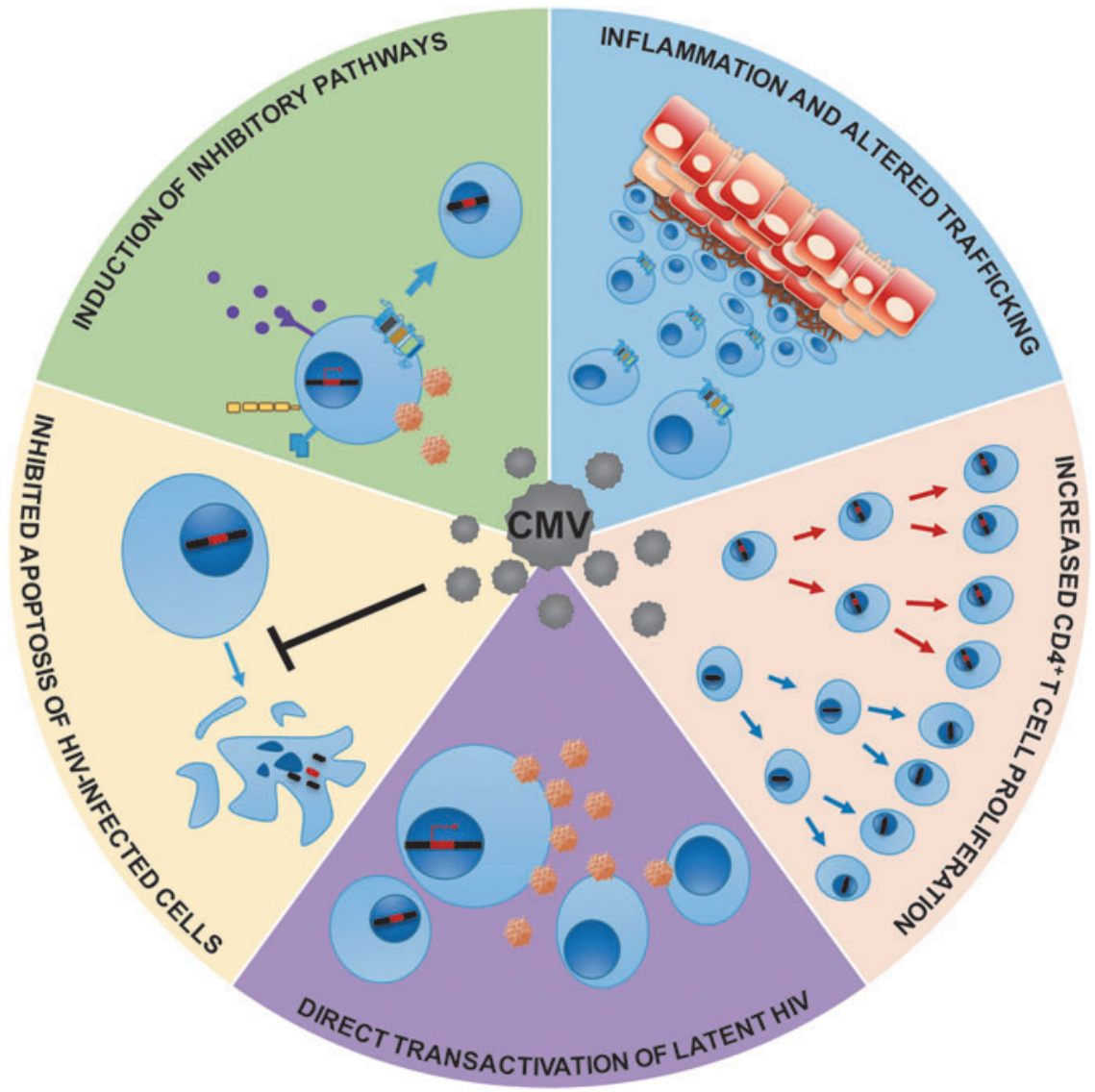

(reviewed in Ref. ${ }^{43}$ ). HIV itself can stimulate the production of IL-10 in vitro, ${ }^{44}$ and IL-10 can inhibit latency reversal in CD4 ${ }^{+}$ $\mathrm{T}$ cells and primary human macrophages in vitro. ${ }^{45}$ This theory is supported by lymphocytic choriomeningitis virus models, which show that upregulation of IL-10 production by antigenpresenting cells is associated with impairment of $\mathrm{T}$ cell functions, thus allowing viral persistence. ${ }^{46,47}$ Inhibition of HIV replication by IL-10 has been demonstrated in vitro, ${ }^{48}$ and high IL-10 plasma levels are associated with the control of viral replication during pregnancy. ${ }^{49}$ This has implications for the reservoir because otherwise productively infected cells may become quiescent through IL-10 expression.

Interestingly, CMV encodes for several viral homologues of human IL-10 (hIL-10) produced through alternative splicing of the UL111A gene. ${ }^{50}$ The predominant form of viral IL-10, cmvIL-10, which despite having only $27 \%$ amino acid sequence identity to hIL-10, binds with high affinity to the hIL-10 receptor. ${ }^{51}$ Furthermore, cmvIL-10 triggers the same antiinflammatory effects as hIL-10. In particular, cmvIL-10 impairs maturation of dendritic cells, downregulates surface HLA expression, inhibits inflammatory cytokine production and cell proliferation, activates transcription factor Stat3, and upregulates hIL-10 expression to further promote an immunosuppressive environment during infection (reviewed in Ref. ${ }^{52}$ ). The second predominant viral IL-10, latency-associated cmvIL-10 (LAcmvIL-10), has been described in a model of latently infected granulocyte macrophage progenitor cells. ${ }^{53}$ LAcmvIL-10 lacks some IL-10R contact residues because of its truncated C-terminus and thus retains some, but not all, of the immunosuppressive functions of cmvIL-10. ${ }^{53} \mathrm{CMV}$-mediated
IL-10 signaling participates in preventing immune responses, thus indirectly favoring HIV persistence. Collectively, these findings suggest that HIV and CMV both hijack IL-10 and PD1 signaling. Future studies should address the mechanisms by which IL-10 and PD-1 benefit CMV and HIV replication, or if they influence the size of the latent reservoir in vivo.

\section{Proliferation and clonal expansion of HIV-infected cells}

The homeostatic proliferation of memory $\mathrm{T}$ cells is one mechanism by which we maintain long-lived immunological memory. Stem cell memory $\mathrm{T}$ (Tscm) cells are particularly relevant to this process and to the HIV reservoir, as Tscm cells from people with HIV have the highest levels of per cell copies of integrated provirus. ${ }^{54}$ Homeostasis of the latent HIV reservoir can be preserved, in part, through the selfrenewal capacity of the Tscm cell subset. ${ }^{54}$ Functional, CMV-specific Tscm cells are present in people with CMV, but absent in CMV negative control donors. ${ }^{55}$ Therefore, it is theoretically possible for a subset of CMV-specific stem cells to replenish the HIV reservoir despite ART through homeostatic proliferation.

Evidence that clonal expansion contributes to HIV persistence is even more compelling. Genetic analyses of HIV proviruses and integration sites in people with HIV who are ART-suppressed provide strong evidence for clonal expansion of HIV-infected $\mathrm{CD}^{+}{ }^{+} \mathrm{T}$ cells as a crucial mechanism of viral persistence during suppressive ART. ${ }^{56-60}$ Self-renewal capacity of memory $\mathrm{CD}^{+} \mathrm{T}$ cells is important to maintain immunological memory and can be driven by homeostatic 
responses to $\mathrm{CD}^{+} \mathrm{T}$ cell depletion and inflammation, or directly by antigen stimulation (such as HIV or CMV). ${ }^{61,62}$ Antigen dose affects immune responses, potentially turning initial inflammation into immune exhaustion at different rates. ${ }^{63} \mathrm{CMV}$ antigens in particular are chronically present at high doses, ${ }^{64}$ and consequently CMV-specific T cells account for a disproportionately large subset of total $\mathrm{T}$ cell memory responses. ${ }^{17}$ This proportion is even greater among HIVinfected adults, and remains high after ART-mediated suppression of HIV replication. ${ }^{65,66}$ Although CMV-specific T cells are relatively resistant to de novo $\mathrm{HIV}$ infection, ${ }^{67} \mathrm{CMV}$-associated immune activation could nonetheless induce proliferation of $\mathrm{T}$ cells, including HIV-infected cells. If CMV-induced $\mathrm{T}$ cell proliferation preferentially affects HIV-infected cells, this may lead to an increase in the HIV latent reservoir.

Studies involving self-renewal and persistent antigenic stimulation of $\mathrm{CD}^{+} \mathrm{T}$ cells leave many unanswered questions. For instance, we do not know whether HIV provirus can compartmentalize and concentrate in distinct subsets of the adaptive immune system, such as CMV-specific cells. If the latent HIV reservoir continuously re-establishes itself in response to $\mathrm{CMV}$-derived antigenic stimulation of the immune system, one might expect that CMV-specific cells would demonstrate heightened levels of proviral DNA with evidence of evolution over time, but this has not been investigated to our knowledge. Little is known about the effects of subclinical CMV replication on key $\mathrm{T}$ cell subsets that contribute to persistence, such as Tscm cells, central memory $\mathrm{T}$ cells, transitional memory $\mathrm{T}$ cells, and $\mathrm{CD} 4^{+} \mathrm{T}$ cells expressing PD-1, TIGIT, and LAG3. ${ }^{41,68}$ IL-7- and IL-15mediated expansion of HIV-infected cells also contribute to persistence during virally suppressive ART, ${ }^{69,70}$ and the influence of CMV on this process is also unknown.

\section{Inhibition of apoptosis}

Abortive HIV infections can induce cell death through cellular sensors of viral products. ${ }^{71,72}$ The rapid loss of $\mathrm{CD} 4^{+} \mathrm{T}$ cells during acute HIV infection is due, in part, to the innate cellular defenses that can trigger apoptosis before HIV successfully integrates. This is an especially important pathway in naive $\mathrm{T}$ cells, which exhibit heightened antiviral defenses but are prone to remain quiescent and latent upon successful HIV integration. ${ }^{73} \mathrm{CMV}$ may interfere with protective immunity against HIV through the blocking of this defensive apoptosis: CMV is armed with two proteins that inhibit apoptosis, viral mitochondrial-localized inhibitor of apoptosis (vMIA) and viral inhibitor of Caspase-8-induced apoptosis (vICA). ${ }^{74}$ vMIA blocks apoptosis by inhibiting cytochrome $\mathrm{C}$ release from mitochondrial membranes and vICA blocks apoptosis by interfering with the activation of Caspase 8 (reviewed in Ref. ${ }^{75}$ ). Neither of these proteins has been studied specifically in the context of HIV-infected cells. Blocked apoptosis might, therefore, allow a more robust seeding of the latent reservoir, especially during acute HIV infection. CMV-encoded inhibitors of apoptosis should be evaluated for their effects on the size of the HIV reservoir and their ability to promote de novo HIV infections of quiescent cells.

\section{Direct transactivation of latent HIV by CMV}

Although CMV does not generally infect $\mathrm{CD}^{+} \mathrm{T}$ cells, CMV replication could nonetheless promote inflammation and HIV persistence by inducing compartmentalized, ongoing HIV RNA expression in effector tissues, despite ART suppression. This is likely made possible through secreted mediators of inflammation and/or altered cell-mediated immunity, since HIV preferentially integrates into actively transcribed regions, rendering its expression particularly susceptible to regulation by host transcription factors. ${ }^{76}$ Evidence from as early as 1990 has supported the concept that CMV (especially immediate early genes) can induce HIV expression by manipulating cellular transcription pathways. $^{77}$ In a related study, CMV infection significantly increased HIV long terminal repeat (LTR)-driven reporter gene expression in transfected human fetal astrocytes. ${ }^{78}$

Activation of mammalian target of rapamycin (mTOR) signaling may be involved in the induction of HIV expression by CMV as well. ${ }^{79,80}$ mTOR activation is a common tactic employed by intracellular pathogens to benefit their own replication, ${ }^{81}$ and both $\mathrm{CMV}$ and HIV activate mTOR signaling. ${ }^{79,80}$ Moreover, inhibition of mTOR signaling was shown to not only impair HIV entry and transcription but also decreases viremia in a humanized mouse model of HIV infection. ${ }^{82}$ Interestingly, mTOR also regulates proliferation and inflammation pathways (reviewed in Ref. ${ }^{81}$ ), underscoring the potential importance of mTOR in enabling the chronic, pathogenic effects of HIV and CMV coinfection. In a human monocyte cell line, CMV was shown to induce activation of AP-1 and NF-kappaB. ${ }^{83}$ These transcription factors are critical for efficient transcription of integrated HIV, and NF-kappaB has also been implicated in the establishment of latency. ${ }^{84}$

The effects of CMV on the transcriptional environment of HIV-infected cells are complex, but few studies directly address this topic in vivo, despite the high prevalence of CMV coinfection in people living with HIV. Transacting factors that mediate CMV-induced transcriptional dysregulation, and its effects on latency or HIV expression, merit further investigation.

\section{Conclusions}

The latent reservoir is not static, and the mechanisms by which the latent HIV reservoir is replenished are still poorly understood. Defenses evolved by CMV to commandeer the immune system might create a favorable environment for HIV reservoir seeding, thus representing an additional hurdle to be addressed by successful HIV eradication strategies.

Multiple mechanisms may be responsible for larger HIV reservoirs in the presence of CMV replication (Fig. 1). By changing the development, trafficking, proliferation, apoptosis, and/or transcriptional environment of HIV target cells, CMV slows the decay of the HIV reservoir during ART. ${ }^{1}$ The degree to which each mechanism contributes to the expansion of the HIV reservoir in vivo - under which circumstancesremains unclear, but it is likely that many of them occur simultaneously. For example, persistent inflammation due to CMV could also affect proliferation, susceptibility to apoptosis, and latent HIV transactivation. Thus, synergistic effects between these mechanisms should also be considered. One additional caveat to many CMV and HIV studies is that increased CMV replication could be a consequence of increased inflammation or larger HIV reservoirs. Interventional studies will be required to determine the degree and direction of causality between CMV, HIV, and inflammation. 
Many of the strategies aimed at curing HIV use pharmacological or biological agents to stimulate cells harboring latent HIV, to purge the latent reservoir. ${ }^{85}$ However, activation of latent HIV DNA with immune modulatory interventions could affect replication of CMV and other human herpesviruses, which might, in turn, limit HIV clearance. The effects of latency reversing agents and immune modulatory therapies on CMV reactivation are currently unknown and should be evaluated in clinical trials. Future studies should assess the replication competence of HIV DNA reservoirs in the setting of CMV replication, and should seek to determine whether CMV-induced cell survival and proliferation preferentially affect HIV-infected cells. By examining the role of CMV in promoting HIV persistence, we may reveal pathways to disrupt the latent HIV reservoir, thus aiding successful cure strategies.

\section{Acknowledgments}

We are grateful to Antoine Chaillon for his help designing our figure. We also appreciate Lisa Loeb Stanga and the California HIV Research Program for constructive feedback. This work was supported primarily by a grant from the National Institutes of Health, University of California, San Francisco-Gladstone Institute of Virology \& Immunology Center for AIDS Research, P30-AI027763 (CNIHR), California HIV Research Program Ideal award to Sara Gianella, by the department of Veterans Affairs, the James B. Pendleton Charitable Trust and additional grants from the National Institutes of Health: AI100665, MH100974, MH097520, DA034978, AI007384, AI027763, AI106039, AI43638, AI074621, AI036214, MH101012, UL1TR000100, CARE U19 AI096113, and AI068636-09. The funders had no role in study design, data collection and analysis, decision to publish, or preparation of the article.

\section{Authors' Contributions}

A.C.-Q., C.V., A.L., and S.G. participated in creating the outline design, literature search, and wrote the primary version of the article. All authors read and approved the final article.

\section{Author Disclosure Statement}

No competing financial interests exist.

\section{References}

1. Gianella S, Anderson CM, Var SR, Oliveira MF, Lada SM, Vargas MV, Massanella M, Little SJ, Richman DD, Strain MC, Perez-Santiago J, Smith DM: Replication of human herpesviruses is associated with higher HIV DNA levels during antiretroviral therapy started at early phases of HIV infection. J Virol 2016;90:3944-3952.

2. Gianella S, Massanella M, Richman DD, Little SJ, Spina CA, Vargas MV, Lada SM, Daar ES, Dube MP, Haubrich RH, Morris SR, Smith DM; California Collaborative Treatment Group T: Cytomegalovirus replication in semen is associated with higher levels of proviral HIV DNA and CD4+ T cell activation during antiretroviral treatment. J Virol 2014;88:78187827.

3. Maidji E, Somsouk M, Rivera JM, Hunt PW, Stoddart CA: Replication of CMV in the gut of HIV-infected individuals and epithelial barrier dysfunction. PLoS Pathog 2017;13: e1006202.

4. Brenchley JM, Schacker TW, Ruff LE, Price DA, Taylor JH, Beilman GJ, Nguyen PL, Khoruts A, Larson M, Haase
AT, Douek DC: CD4+ T cell depletion during all stages of HIV disease occurs predominantly in the gastrointestinal tract. J Exp Med 2004;200:749-759.

5. Siliciano JM, Siliciano RF: The remarkable stability of the latent reservoir for HIV-1 in resting memory CD4+ T cells. J Infect Dis 2015;212:1345-1347.

6. Murray AJ, Kwon KJ, Farber DL, Siliciano RF: The latent reservoir for HIV-1: How immunologic memory and clonal expansion contribute to HIV-1 persistence. J Immunol 2016;197:407-417.

7. Durier N, Ananworanich J, Apornpong T, Ubolyam S, Kerr SJ, Mahanontharit A, Ferradini L, Ruxrungtham K, Avihingsanon A: Cytomegalovirus viremia in Thai HIVinfected patients on antiretroviral therapy: Prevalence and associated mortality. Clin Infect Dis 2013;57:147-155.

8. Gianella S, Massanella M, Wertheim JO, Smith DM: The sordid affair between human herpesvirus and HIV. J Infect Dis 2015;212:845-852.

9. Bate SL, Dollard SC, Cannon MJ: Cytomegalovirus seroprevalence in the United States: The national health and nutrition examination surveys, 1988-2004. Clin Infect Dis 2010;50:1439-1447.

10. Freeman ML, Lederman MM, Gianella S: Partners in crime: The role of CMV in immune dysregulation and clinical outcome during HIV infection. Curr HIV/AIDS Rep 2016;13:10-19.

11. Morris SR, Zhao M, Smith DR, Vargas MV, Little SJ, Gianella S: Longitudinal viral dynamics in semen during early HIV infection. Clin Infect Dis. 2017;64: 428-434.

12. Smith DM, Nakazawa M, Freeman ML, Anderson CM, Oliveira MF, Little SJ, Gianella S: Asymptomatic CMV replication during early human immunodeficiency virus (HIV) infection is associated with lower CD4/CD8 ratio during HIV treatment. Clin Infect Dis 2016;63:15171524.

13. Poizot-Martin I, Allavena C, Duvivier C, Cano CE, Guillouet de Salvador F, Rey D, Dellamonica P, Cuzin L, Cheret A, Hoen B, Dat ASG: CMV+ serostatus associates negatively with CD4:CD8 ratio normalization in controlled HIV-infected patients on cART. PLoS One 2016;11: e0165774.

14. Dan JM, Massanella M, Smith DM, Spina CA, Schrier R, Daar ES, Dube MP, Morris SR, Gianella S: Brief report: Effect of CMV and HIV transcription on CD57 and PD-1 T-Cell expression during suppressive ART. J Acquir Immune Defic Syndr 2016;72:133-137.

15. Henrich TJ, Hobbs KS, Hanhauser E, Scully E, Hogan LE, Robles YP, Leadabrand KS, Marty FM, Palmer CD, Jost S, Korner C, Li JZ, Gandhi RT, Hamdan A, Abramson J, LaCasce AS, Kuritzkes DR: Human immunodeficiency virus type 1 persistence following systemic chemotherapy for malignancy. J Infect Dis 2017;216: 254-262.

16. Gianella S, Anderson CM, Vargas MV, Richman DD, Little SJ, Morris SR, Smith DM: CMV DNA in semen and blood is associated with higher levels of proviral HIV DNA. J Infect Dis 2012;207:898-902.

17. Sylwester AW, Mitchell BL, Edgar JB, Taormina C, Pelte C, Ruchti F, Sleath PR, Grabstein KH, Hosken NA, Kern F, Nelson JA, Picker LJ: Broadly targeted human cytomegalovirus-specific CD4+ and CD8+ T cells dominate the memory compartments of exposed subjects. J Exp Med 2005;202:673-685. 
18. Soderberg-Naucler C: Treatment of cytomegalovirus infections beyond acute disease to improve human health. Expert Rev Anti Infect Ther 2014;12:211-222.

19. Lisco A, Vanpouille C, Margolis L: War and peace between microbes: HIV-1 interactions with coinfecting viruses. Cell Host Microbe 2009;6:403-408.

20. Almeida GD, Porada CD, St Jeor S, Ascensao JL: Human cytomegalovirus alters interleukin-6 production by endothelial cells. Blood 1994;83:370-376.

21. Suni MA, Ghanekar SA, Houck DW, Maecker HT, Wormsley SB, Picker LJ, Moss RB, Maino VC: CD4(+)CD8(dim) T lymphocytes exhibit enhanced cytokine expression, proliferation and cytotoxic activity in response to HCMV and HIV-1 antigens. Eur J Immunol 2001;31:2512-2520.

22. Iwamoto GK, Monick MM, Clark BD, Auron PE, Stinski MF, Hunninghake GW: Modulation of interleukin 1 beta gene expression by the immediate early genes of human cytomegalovirus. J Clin Invest 1990;85:1853-1857.

23. Fawaz LM, Sharif-Askari E, Menezes J: Up-regulation of NK cytotoxic activity via IL-15 induction by different viruses: A comparative study. J Immunol 1999;163:44734480.

24. Saghafian-Hedengren S, Sohlberg E, Theorell J, CarvalhoQueiroz C, Nagy N, Persson JO, Nilsson C, Bryceson YT, Sverremark-Ekstrom E: Epstein-Barr virus coinfection in children boosts cytomegalovirus-induced differentiation of natural killer cells. J Virol 2013;87:1344613455.

25. Overwijk WW, Schluns KS: Functions of gammaC cytokines in immune homeostasis: Current and potential clinical applications. Clin Immunol 2009;132:153-165.

26. Chang WL, Baumgarth N, Yu D, Barry PA: Human cytomegalovirus-encoded interleukin-10 homolog inhibits maturation of dendritic cells and alters their functionality. J Virol 2004;78:8720-8731.

27. Kotenko SV, Saccani S, Izotova LS, Mirochnitchenko OV, Pestka S: Human cytomegalovirus harbors its own unique IL-10 homolog (cmvIL-10). Proc Natl Acad Sci U S A 2000;97:1695-1700.

28. Hamilton ST, Scott GM, Naing Z, Rawlinson WD: Human cytomegalovirus directly modulates expression of chemokine CCL2 (MCP-1) during viral replication. J Gen Virol 2013;94:2495-2503.

29. Johnson EL, Howard CL, Thurman J, Pontiff K, Johnson ES, Chakraborty R: CMV upregulates expression of CCR5 in central memory TCM cord blood mononuclear cells which may facilitate in utero HIV-1 transmission. J Infect Dis 2014 [Epub ahead of print]; DOI:10.1093/infdis/jiu424.

30. Dragic T, Litwin V, Allaway GP, Martin SR, Huang Y, Nagashima KA, Cayanan C, Maddon PJ, Koup RA, Moore JP, Paxton WA: HIV-1 entry into CD4+ cells is mediated by the chemokine receptor CC-CKR-5. Nature 1996;381: 667-673.

31. Gianella S, Chaillon A, Mutlu EA, Engen PA, Voigt RM, Keshavarzian A, Losurdo J, Chakradeo P, Lada SM, Nakazawa M, Landay AL: Effect of CMV and EBV replication on intestinal mucosal gene expression and microbiome composition of HIV-infected and uninfected individuals. AIDS 2017;31:2059-2067.

32. Ulbrecht M, Martinozzi S, Grzeschik M, Hengel H, Ellwart JW, Pla M, Weiss EH: Cutting edge: The human cytomegalovirus UL40 gene product contains a ligand for HLA$\mathrm{E}$ and prevents NK cell-mediated lysis. J Immunol 2000; 164:5019-5022.
33. Soderberg-Naucler C: Human cytomegalovirus persists in its host and attacks and avoids elimination by the immune system. Crit Rev Immunol 2006;26:231-264.

34. Barnes PD, Grundy JE: Down-regulation of the class I HLA heterodimer and beta 2-microglobulin on the surface of cells infected with cytomegalovirus. J Gen Virol 1992;73 (Pt 9):2395-2403.

35. Powers C, DeFilippis V, Malouli D, Fruh K: Cytomegalovirus immune evasion. Curr Top Microbiol Immunol 2008;325:333-359.

36. Johnson DC, Hegde NR: Inhibition of the MHC class II antigen presentation pathway by human cytomegalovirus. Curr Top Microbiol Immunol 2002;269:101-115.

37. D'Souza M, Fontenot AP, Mack DG, Lozupone C, Dillon S, Meditz A, Wilson CC, Connick E, Palmer BE: Programmed death 1 expression on HIV-specific CD4+ T cells is driven by viral replication and associated with $\mathrm{T}$ cell dysfunction. J Immunol 2007;179:1979-1987.

38. Kaufmann DE, Kavanagh DG, Pereyra F, Zaunders JJ, Mackey EW, Miura T, Palmer S, Brockman M, Rathod A, Piechocka-Trocha A, Baker B, Zhu B, Le Gall S, Waring MT, Ahern R, Moss K, Kelleher AD, Coffin JM, Freeman GJ, Rosenberg ES, Walker BD: Upregulation of CTLA-4 by $\mathrm{HIV}$-specific CD4+ $\mathrm{T}$ cells correlates with disease progression and defines a reversible immune dysfunction. Nat Immunol 2007;8:1246-1254.

39. Chomont N, El-Far M, Ancuta P, Trautmann L, Procopio FA, Yassine-Diab B, Boucher G, Boulassel MR, Ghattas G, Brenchley JM, Schacker TW, Hill BJ, Douek DC, Routy JP, Haddad EK, Sekaly RP: HIV reservoir size and persistence are driven by $\mathrm{T}$ cell survival and homeostatic proliferation. Nat Med 2009;15:893-900.

40. Hatano H, Jain V, Hunt PW, Lee TH, Sinclair E, Do TD, Hoh R, Martin JN, McCune JM, Hecht F, Busch MP, Deeks SG: Cell-based measures of viral persistence are associated with immune activation and programmed cell death protein 1 (PD-1)-expressing CD4+ T cells. J Infect Dis 2012 [Epub ahead of print]; DOI:10.1093/infdis/jis630.

41. Trautmann L, Janbazian L, Chomont N, Said EA, Gimmig S, Bessette B, Boulassel MR, Delwart E, Sepulveda H, Balderas RS, Routy JP, Haddad EK, Sekaly RP: Upregulation of PD-1 expression on HIV-specific CD8+ T cells leads to reversible immune dysfunction. Nat Med 2006;12:1198-1202.

42. Keir ME, Butte MJ, Freeman GJ, Sharpe AH: PD-1 and its ligands in tolerance and immunity. Annu Rev Immunol 2008;26:677-704.

43. Wilson EB, Brooks DG: The role of IL-10 in regulating immunity to persistent viral infections. Curr Top Microbiol Immunol 2011;350:39-65.

44. Masood R, Lunardi-Iskandar Y, Moudgil T, Zhang Y, Law RE, Huang CL, Puri RK, Levine AM, Gill PS: IL-10 inhibits HIV-1 replication and is induced by tat. Biochem Biophys Res Commun 1994;202:374-383.

45. Montaner LJ, Griffin P, Gordon S: Interleukin-10 inhibits initial reverse transcription of human immunodeficiency virus type 1 and mediates a virostatic latent state in primary blood-derived human macrophages in vitro. J Gen Virol 1994;75 (Pt 12):3393-3400.

46. Brooks DG, Trifilo MJ, Edelmann KH, Teyton L, McGavern $\mathrm{DB}$, Oldstone MB: Interleukin-10 determines viral clearance or persistence in vivo. Nat Med 2006;12:13011309.

47. Ejrnaes M, Filippi CM, Martinic MM, Ling EM, Togher LM, Crotty S, von Herrath MG: Resolution of a chronic 
viral infection after interleukin-10 receptor blockade. J Exp Med 2006;203:2461-2472.

48. Arias JF, Nishihara R, Bala M, Ikuta K: High systemic levels of interleukin-10, interleukin-22 and C-reactive protein in Indian patients are associated with low in vitro replication of HIV-1 subtype C viruses. Retrovirology 2010;7:15.

49. Bento CA, Hygino J, Andrade RM, Saramago CS, Silva RG, Silva AA, Linhares UC, Brindeiro R, Tanuri A, Rosenzwajg M, Klatzmann D, Andrade AF: IL-10-secreting T cells from HIV-infected pregnant women downregulate HIV-1 replication: Effect enhanced by antiretroviral treatment. AIDS 2009;23:9-18.

50. Lin YL, Chang PC, Wang Y, Li M: Identification of novel viral interleukin-10 isoforms of human cytomegalovirus AD169. Virus Res 2008;131:213-223.

51. Slobedman B, Barry PA, Spencer JV, Avdic S, Abendroth A: Virus-encoded homologs of cellular interleukin-10 and their control of host immune function. J Virol 2009;83:9618-9629.

52. McSharry BP, Avdic S, Slobedman B: Human cytomegalovirus encoded homologs of cytokines, chemokines and their receptors: Roles in immunomodulation. Viruses 2012;4:2448-2470.

53. Jenkins C, Garcia W, Godwin MJ, Spencer JV, Stern JL, Abendroth A, Slobedman B: Immunomodulatory properties of a viral homolog of human interleukin-10 expressed by human cytomegalovirus during the latent phase of infection. J Virol 2008;82:3736-3750.

54. Buzon MJ, Sun H, Li C, Shaw A, Seiss K, Ouyang Z, Martin-Gayo E, Leng J, Henrich TJ, Li JZ, Pereyra F, Zurakowski R, Walker BD, Rosenberg ES, Yu XG, Lichterfeld M: HIV-1 persistence in CD4+ T cells with stem cell-like properties. Nat Med 2014;20:139-142.

55. Schmueck-Henneresse M, Sharaf R, Vogt K, Weist BJ, Landwehr-Kenzel S, Fuehrer H, Jurisch A, Babel N, Rooney CM, Reinke P, Volk HD: Peripheral blood-derived virus-specific memory stem $\mathrm{T}$ cells mature to functional effector memory subsets with self-renewal potency. J Immunol 2015;194:5559-5567.

56. von Stockenstrom S, Odevall L, Lee E, Sinclair E, Bacchetti P, Killian M, Epling L, Shao W, Hoh R, Ho T, Faria NR, Lemey P, Albert J, Hunt P, Loeb L, Pilcher C, Poole L, Hatano H, Somsouk M, Douek D, Boritz E, Deeks SG, Hecht FM, Palmer S: Longitudinal genetic characterization reveals that cell proliferation maintains a persistent HIV type 1 DNA pool during effective HIV therapy. J Infect Dis 2015;212:596-607.

57. Wagner TA, McKernan JL, Tobin NH, Tapia KA, Mullins JI, Frenkel LM: An increasing proportion of monotypic HIV-1 DNA sequences during antiretroviral treatment suggests proliferation of HIV-infected cells. J Virol 2013;87:17701778.

58. Maldarelli F, Wu X, Su L, Simonetti FR, Shao W, Hill S, Spindler J, Ferris AL, Mellors JW, Kearney MF, Coffin JM, Hughes SH: HIV latency. Specific HIV integration sites are linked to clonal expansion and persistence of infected cells. Science 2014;345:179-183.

59. Wagner TA, McLaughlin S, Garg K, Cheung CY, Larsen BB, Styrchak S, Huang HC, Edlefsen PT, Mullins JI, Frenkel LM: HIV latency. Proliferation of cells with HIV integrated into cancer genes contributes to persistent infection. Science 2014;345:570-573.

60. Cohn LB, Silva IT, Oliveira TY, Rosales RA, Parrish EH, Learn GH, Hahn BH, Czartoski JL, McElrath MJ, Lehmann C, Klein F, Caskey M, Walker BD, Siliciano JD, Siliciano
RF, Jankovic M, Nussenzweig MC: HIV-1 integration landscape during latent and active infection. Cell 2015;160:420 432.

61. Chahroudi A, Silvestri G, Lichterfeld M: T memory stem cells and HIV: A long-term relationship. Curr HIV/AIDS Rep 2015;12:33-40.

62. Klatt NR, Bosinger SE, Peck M, Richert-Spuhler LE, Heigele A, Gile JP, Patel N, Taaffe J, Julg B, Camerini D, Torti C, Martin JN, Deeks SG, Sinclair E, Hecht FM, Lederman MM, Paiardini M, Kirchhoff F, Brenchley JM, Hunt PW, Silvestri G: Limited HIV infection of central memory and stem cell memory CD4+ T cells is associated with lack of progression in viremic individuals. PLoS Pathog 2014;10:e1004345.

63. Han S, Asoyan A, Rabenstein H, Nakano N, Obst R: Role of antigen persistence and dose for CD4+ T-cell exhaustion and recovery. Proc Natl Acad Sci U S A 2010;107:2045320458.

64. Frey SE, Harrison C, Pass RF, Yang E, Boken D, Sekulovich RE, Percell S, Izu AE, Hirabayashi S, Burke RL, Duliege AM: Effects of antigen dose and immunization regimens on antibody responses to a cytomegalovirus glycoprotein B subunit vaccine. J Infect Dis 1999;180:1700-1703.

65. Stone SF, Price P, Khan N, Moss PA, French MA: HIV patients on antiretroviral therapy have high frequencies of CD8 T cells specific for Immediate Early protein-1 of cytomegalovirus. AIDS 2005;19:555-562.

66. Naeger DM, Martin JN, Sinclair E, Hunt PW, Bangsberg DR, Hecht F, Hsue P, McCune JM, Deeks SG: Cytomegalovirus-specific $\mathrm{T}$ cells persist at very high levels during long-term antiretroviral treatment of HIV disease. PLoS One 2010;5:e8886.

67. Casazza JP, Brenchley JM, Hill BJ, Ayana R, Ambrozak D, Roederer M, Douek DC, Betts MR, Koup RA: Autocrine production of beta-chemokines protects CMV-Specific CD4 T cells from HIV infection. PLoS Pathog 2009;5: e1000646.

68. Fromentin R, Bakeman W, Lawani MB, Khoury G, Hartogensis W, DaFonseca S, Killian M, Epling L, Hoh R, Sinclair E, Hecht FM, Bacchetti P, Deeks SG, Lewin SR, Sekaly RP, Chomont N: CD4+ T cells expressing PD-1, TIGIT and LAG-3 contribute to HIV persistence during ART. PLoS Pathog 2016;12:e1005761.

69. Vandergeeten C, Fromentin R, DaFonseca S, Lawani MB, Sereti I, Lederman MM, Ramgopal M, Routy JP, Sekaly RP, Chomont N: Interleukin-7 promotes HIV persistence during antiretroviral therapy. Blood 2013;121:4321-4329.

70. Tsunetsugu-Yokota Y, Kobayahi-Ishihara M, Wada Y, Terahara K, Takeyama H, Kawana-Tachikawa A, Tokunaga K, Yamagishi M, Martinez JP, Meyerhans A: Homeostatically maintained resting naive CD4+ T cells resist latent HIV reactivation. Front Microbiol 2016;7:1944.

71. Cooper A, Garcia M, Petrovas C, Yamamoto T, Koup RA, Nabel GJ: HIV-1 causes CD4 cell death through DNAdependent protein kinase during viral integration. Nature 2013;498:376-379.

72. Jakobsen MR, Bak RO, Andersen A, Berg RK, Jensen SB, Tengchuan J, Laustsen A, Hansen K, Ostergaard L, Fitzgerald KA, Xiao TS, Mikkelsen JG, Mogensen TH, Paludan SR: IFI16 senses DNA forms of the lentiviral replication cycle and controls HIV-1 replication. Proc Natl Acad Sci U S A 2013;110:E4571-E4580.

73. Klein D: HIV latency in naive T cells. Trends Mol Med 2001;7:285. 
74. McCormick AL, Skaletskaya A, Barry PA, Mocarski ES, Goldmacher VS: Differential function and expression of the viral inhibitor of caspase 8-induced apoptosis (vICA) and the viral mitochondria-localized inhibitor of apoptosis (vMIA) cell death suppressors conserved in primate and rodent cytomegaloviruses. Virology 2003;316:221-233.

75. Goldmacher VS: Cell death suppression by cytomegaloviruses. Apoptosis 2005;10:251-265.

76. Schroder AR, Shinn P, Chen H, Berry C, Ecker JR, Bushman F: HIV-1 integration in the human genome favors active genes and local hotspots. Cell 2002;110:521-529.

77. Barry PA, Pratt-Lowe E, Peterlin BM, Luciw PA: Cytomegalovirus activates transcription directed by the long terminal repeat of human immunodeficiency virus type 1 . J Virol 1990;64:2932-2940.

78. McCarthy M, Auger D, He J, Wood C: Cytomegalovirus and human herpesvirus- 6 trans-activate the HIV-1 long terminal repeat via multiple response regions in human fetal astrocytes. J Neurovirol 1998;4:495-511.

79. Walsh D, Perez C, Notary J, Mohr I: Regulation of the translation initiation factor eIF4F by multiple mechanisms in human cytomegalovirus-infected cells. J Virol 2005;79: 8057-8064.

80. van der Vlist M, van der Aar AM, Gringhuis SI, Geijtenbeek TB: Innate signaling in HIV-1 infection of dendritic cells. Curr Opin HIV AIDS 2011;6:348-352.

81. Brunton J, Steele S, Ziehr B, Moorman N, Kawula T: Feeding uninvited guests: mTOR and AMPK set the table for intracellular pathogens. PLoS Pathog 2013;9:e1003552.

82. Heredia A, Le N, Gartenhaus RB, Sausville E, MedinaMoreno S, Zapata JC, Davis C, Gallo RC, Redfield RR:
Targeting of mTOR catalytic site inhibits multiple steps of the HIV-1 lifecycle and suppresses HIV-1 viremia in humanized mice. Proc Natl Acad Sci U S A 2015;112:9412-9417.

83. Murayama T, Ohara Y, Obuchi M, Khabar KS, Higashi H, Mukaida N, Matsushima K: Human cytomegalovirus induces interleukin- 8 production by a human monocytic cell line, THP-1, through acting concurrently on AP-1- and NFkappaB-binding sites of the interleukin- 8 gene. J Virol 1997;71:5692-5695.

84. Saleh S, Lu HK, Evans V, Harisson D, Zhou J, Jaworowski A, Sallmann G, Cheong KY, Mota TM, Tennakoon S, Angelovich TA, Anderson J, Harman A, Cunningham A, Gray L, Churchill M, Mak J, Drummer H, Vatakis DN, Lewin SR, Cameron PU: HIV integration and the establishment of latency in CCL19-treated resting CD4(+) T cells require activation of NF-kappaB. Retrovirology 2016;13:49.

85. Banga R, Procopio FA, Cavassini M, Perreau M: In vitro reactivation of replication-competent and infectious HIV-1 by histone deacetylase inhibitors. J Virol 2015;90:1858-1871.

Address correspondence to: Sara Gianella Department of Medicine University of California San Diego Center for AIDS Research 9500 Gilman Drive MC 0679 La Jolla, CA 92093-0679

E-mail: gianella@ucsd.edu 